\title{
A PROJECT MANAGEMENT GEOINFORMATICS UTILITY FOR HEALTH PROTECTION AND SANITARY DRAWINGS IN GREEN CONSTRUCTIONS - INFRASTRUCTURE WORKS
}

\author{
TILEMACHOS KOLIOPOULOS ${ }^{* 1}$, SOKRATIS THEOCHARATOS ${ }^{2}$, \\ PANAGIOTIS KOULOUMPIS ${ }^{2}$, CRINA RADU ${ }^{3}$, ION CRISTEA ${ }^{3}$ \\ ${ }^{I}$ Telegeco Research Centre - University of West Attica, Department of Public Health \& \\ Community Health, Athens, Greece \\ ${ }^{2}$ Telegeco Research Centre, Athens, Greece \\ 3 "Vasile Alecsandri" University of Bacau, Calea Marasesti 157, Bacau, 600115, Romania
}

\begin{abstract}
This research study analyses the life cycle assessment of different waste management techniques and sanitary drawings in landfilled waste treatment units' biotechnology at Community Health Centres design for the protection of Public Health from biogas emissions, leachate hazardous toxic acids and landfill biomass biodegradation stages. The environmental impact assessment is examined of associative pollution spaces of Community Health Centres minimising the relative public health's risks. Moreover, it examines the significance of phytobioremediation techniques for landfills' heavy metal concentrations and associated risks minimisation. Reclamation works are examined in associated risks minimisation of toxic hazardous concentrations that could enter in water resources, food chain and agricultural resources. A useful geoinformatics utility is presented in this research study for project management of associated infrastructures in green sustainable construction designs; the optimum operation of Health Centres and associated infratructures for the protection of Public Health.
\end{abstract}

Keywords: Public health, sanitary drawings, sustainable designs, hydraulics, machines, geotechnics, bio-economy, mitigation of pollution, geoinformatics utilities, project management

\section{INTRODUCTION}

Environmental management is the discipline that is concerned with resources once society requires them. In an effort to meet growing environmental awareness, most industrial companies include in their plan investments that are related to the protection of the environment. It is necessary to manage the environmental resources in an sustainable way by minimizing the environmental impacts related to the operation of an environmental system [1-3]. The quality of a complicate environmental system begins to be problem when is demanded the simultaneously cover of its needs and the environmental effects of such system arise and become an environmental public health risk. Then the improvement of the monitoring and proper quality management of environmental systems is necessary $[1,4-6]$.

The effectiveness of an Environmental System which is related to an Efficient Sustainable Design of a Care Communal Building Facility is dependent a huge amount of energy management saving, recovery of waste

\footnotetext{
* Corresponding author, email: telegeco@gmail.com
}

(C) 2018 Alma Mater Publishing House 
emissions and exploitation, taking into account the particular systems' characteristics so as to conserve our natural resources [2, 3, 5, 7-14]. However, International Standards Organization (ISO) organization has published a series of certified systems like ISO 14001 for the protection and certification of quality; environmental management; health and safety respectively $[1,7,15]$. The continuous life cycle analysis of an environmental system is necessary. Monitoring schemes and inspections should be made frequently especially in emergencies not only to protect the optimum operation but also to support the necessities of a complicate environmental system.

\section{GREEN CONSTRUCTIONS AT COMMUNITY HEALTH CENTRES FOR PUBLIC HEALTH PROTECTION}

Proper construction infrastructures and manufactures should be installed for energy exploitation of biogas production in landfill units that exist close to health care community centers avoiding odors, emissions of volatile organic carbons, landfill gas explosions, noises, fires etc. A geoinformation utility is presented to provide sanitary drawings for landfill gas pumping protecting public health. Waste pretreatment by wet pulverisation and leachate recirculation showed that long term pollution loads and associated risks of produced leachates are minimised in short time period i.e magnitudes of C.O.D, T.O.C concentrations are minimised in almost half concentrations $[3,6,11-13,16-18]$. In this way are protected water resources, associated environmental impacts as well as public health from long term risks and associated hazards. Proper drainage works and waste treatment works for leachates should take place so to minimise associated environmental impacts in groundwater pollution protecting public health $[1,6,17,18]$.

Successful integration of ergonomic accessible communal design into the whole health care operational process requires careful consideration of potentially life cycle goals for a sustainable project at its earliest stages. The design should be focused on sustainability of current land uses as well as future building expansions and mobility urban facilities in order to meet project challenges for people with MSD's. Nursing staff, physicians and patients should be in a health care communal unit that follows a construction design and manufactures with new construction materials, technologies and associative innovations which are supporting operational sustainability, effective building systems in energy consumption, support renewable resources from produced landfill gas, health and safety, safe pathways in emergencies, security in road zones and mobility for people with disabilities to access easily the particular facilities of a communal health center. Safe pathways should be properly designed for a successful building evacuation in case of earthquakes, fires, floods, landfill gas explosions or other associated risks $[2,3,8,11,13,19]$. An integrated waste management landfill facility should exist at a communal health care facility in order not only to recover the produced emissions but also to support proper technologies for monitoring and controlling proper environmental hazards in emergencies $[1,4,7,11,12$, $13,16]$.

Proper monitoring and design for leachate treatment emissions should exist as well as a good drainage design for irrigation plants in the surrounded phytoremediation plants site of a communal health care building should exist taking into account flood event risk. Treated sewage sludge could be used properly in phytoremediation plants to bioremediate polluted soil substrates due to leakage of leachates with heavy metals $[6,8,17,18]$.

\section{USEFUL GEOINFORMATIC UTILITY AND RESULTS}

An Effective Sustainable Design of a Care Communal Building Facility for People with particular Disorders should be combined with an efficient design of a Community Health Construction Infrastructure and Public Health Protection in the case of emergencies. Proper corridors in closed system building providing easy access to open spaces should exist applying properly drainage; flood protection pipe networks; earthquake and fire protection designs on given topographies and building architectures of Community and Public Health Infrastructures. 

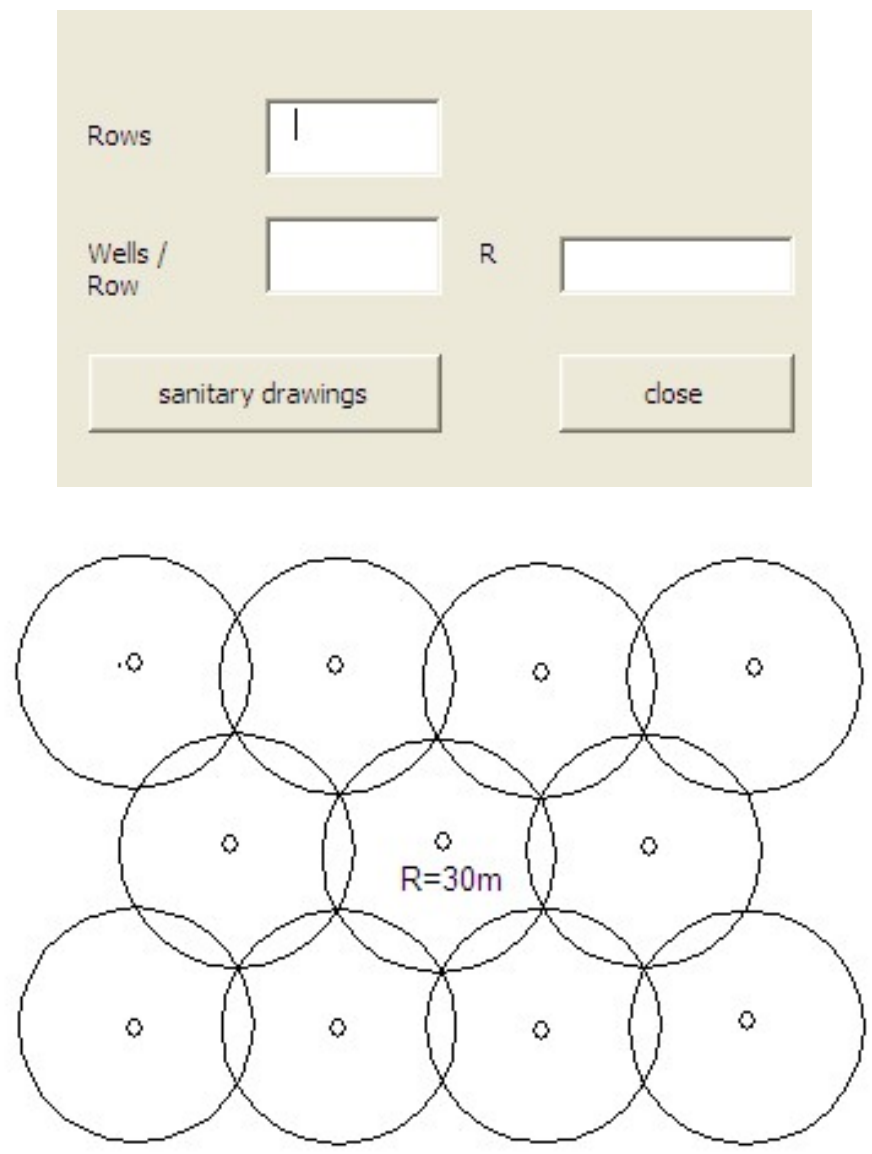

Fig. 1. Indicative front end and results applying properly a geoinformatic utility for sanitary drawings in biogas pumping and public health protection

In Figure 1 is presented a sanitary drawing which is automatically created in ACAD VBA macros environment by the development and proper application of the examining geoinformatic utility, which takes into account the next equations and relative parameters as input data to its calculations. $\mathrm{R}$ is the radius of influence given as input data in the examining geoinformation software in ACAD VBA macros environment so as to be taken into account in the associative designs; project management; monitoring systems; health - safety; mitigation of pollution; and sustainable constructions for bio-economy [5, 10, 20].

It is a useful geoinformation tool for public, community health, environmental protection so as to avoid associated health risks from landfill gas emissions i.e. V.O.C's; biogas explosions; noises; fires; odors; other toxic and hazardous emissions $[1,4,13-15]$.

The velocity between the radius of influence and radius of biogas well is calculated based on equation (1).

$$
V_{\rho}=\frac{\pi\left(r_{i}^{2}-r_{w}^{2}\right) h q D}{2 \pi r_{i} h}
$$

where: $V_{r}$ is the gas velocity in radius $r, r_{i}$ - the radius of influence, $r_{w}$ - the radius of the well, D - the density of the waste mass, $\mathrm{q}$ - the biogas production, $\mathrm{h}$ - the depth of the well.

According to Darcy flow equation we will have

$$
V_{\rho}=-\frac{K}{\mu} \frac{d P}{d r}
$$


where: $\mathrm{K}$ is the hydraulic conductivity, $\mathrm{dP}$ - the pressure difference between the $\mathrm{r}_{\mathrm{i}}$ and $\mathrm{r}_{\mathrm{w}}, \mathrm{m}$ - gas viscosity. Based in equations (1), (2) and integrating their variables it yields:

$$
-\frac{K}{\mu} \int_{r w}^{r i} \frac{d P}{d r}=\int_{r w}^{r i} \frac{\pi\left(r_{i}^{2}-r_{w}^{2}\right) q D}{2 \pi r}
$$

Or

$$
\frac{\Delta \mathrm{P}}{C_{2}}=\frac{q}{2}\left(r_{i}^{2} \ln \frac{r_{i}}{r_{w}}-\frac{r_{i}^{2}-r_{w}^{2}}{2}\right)
$$

The equation (4) is solved in the next chart for $C_{2}=\frac{\mu D}{K}=1.72 * \mathrm{E}-4$ and $\mathrm{r}_{\mathrm{i}}=0.1 \mathrm{~m}$.

There were selected magnitudes in biogas production $\mathrm{q}$ that are equivalent to a landfilled biomass with not high disposed quantities of fermentable materials (Figure 2).

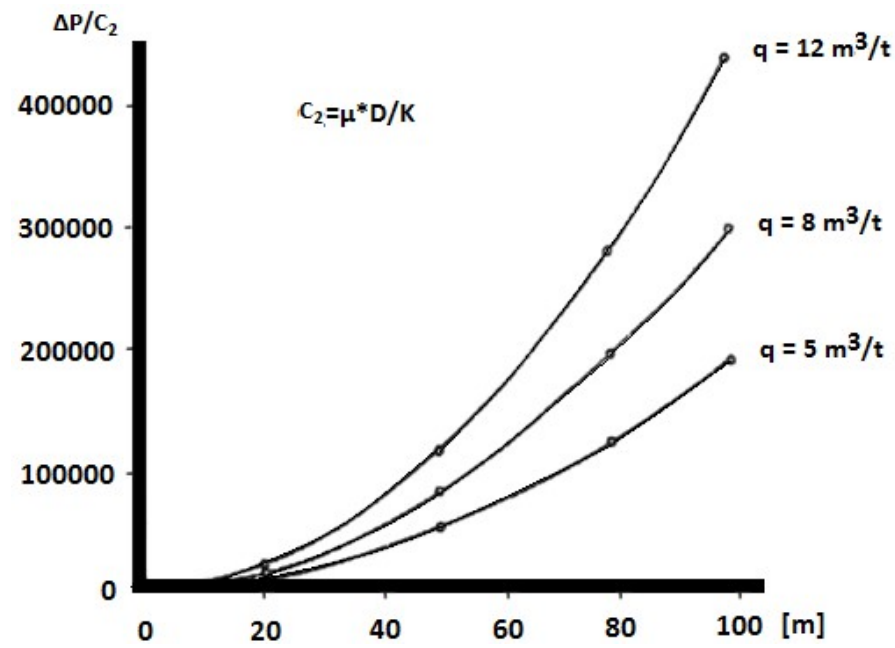

Fig. 2. Indicative solutions for a landfill gas exploitation system in biogas pumping and public health protection.

The next points should be taken into account:

1. Define the needs of a community - public health building construction facility.

2. Set goals for preparedness and response planning.

3. Determine the risks and hazards the community faces.

4. Identify and establish the emergency management preparedness and response team.

5. Risk assessment and determine current capacities and capabilities.

6. Develop the training plan for staff in monitoring schemes to minimise environmental impacts.

7. Ensure thorough communication planning.

8. Ensure thorough mental health planning.

9. Identify, cultivate, and sustain funding sources.

10. Ensure thorough planning related to vulnerable populations.

11. Train, exercise, and drill collaboratively.

12. Critique and improve the integrated community plan.

13. Sustain collaboration, communication, and coordination.

14. Risk assessment of the associated operational needs and resources needs of a community - public health building construction facility in emergencies. 
The presented geoinformatic utility could be used by working staff of a communal health center or other associated infrastructures so as to determine the right installation and operation of manufactures. In this way there is protection for the public health and particular operational productive facilities from hazardous landfill gas emissions and associated risks in indoors and outdoors spaces of a health center's integrated infrastructure.

\section{CONCLUSIONS}

Dynamic spatial models are necessary not only to evaluate particular environmental indexes and associated risks but also to demonstrate efficient sustainable designs that minimize any associated environmental impacts to indoors and outdoors spaces to receptors. In the examining case study a useful geoinformatic utility presented determining the needful installation of pumping systems of an environmental system for biogas exploitation using proper system analysis.

The results by the application of the examining geoinformatic utility are satisfied for determining the right capacities and the successful operational design of an integrated environmental management in biogas exploitation and public health protection.

The associated ISO standards and environmental management systems should be followed during the inspection, construction, operational management and maintenance of an environmental system. Field data are of great importance, not only for making estimations, comparisons and predictions, but also for calibrating field data in mathematical models in order to develop useful risk assessments; geoinformation tools; monitoring schemes; mitigation of pollution; operational project management; maintenance of sustainable designs and take the right measures in indoors and outdoors spaces in emergencies in time.

\section{REFERENCES}

[1] Aldrich, T., Griffith, Environmental Epidemiology and Risk Assessment, Editure Reinhold, N.Y. U.S.A., 1993.

[2] ISO 14001:2015, Standards and Regulations for Investigation, Monitoring, Management, Certification and Improvement of Environmental Systems, ISO Publications, 2015.

[3] Koliopoulos, T., Koliopoulou, G., Controlling Landfill Emissions for Environmental Protection: Mid Auchencarroch Experimental Project, Asian Journal of Experimental Sciences, vol. 20, no. 2, 2006, p. 233-242.

[4] Babatsikou, F., Koliopoulos, T., Koutis, C., Efficient design of a community health infrastructure and public health protection in emergencies, Review Clinical pharmacology and pharmakokinetics, International Edition, Pharmakon Press, vol. 31, 2017, p. 79-84.

[5] Jones, C.B., Geographical Information Systems and Computer Cartography, Longman Press, 1997.

[6] Mackenzie, D., Cornwell, D., Introduction to Environmental Engineering, McGraw Hill, USA, 1998.

[7] American AGIHR Industrial Ventilation: A Manual of Recommended Practice for Design, Editure American CGI Hygienists, 2013.

[8] Ciarkowska, K., Hanus-Fajerska, E., Gambus, F., Muszynska, E., Czech, T., Phytostabilization of Zn-Pb ore flotation tailings ore flotation tailings with Dianthus carthusianorum and Biscuetella laevigata after amending with mineral fertilizers or sewage sludge, Journal of Environmental Management, vol. 189, 2017, p. 75-83.

[9] Hughes, A., Electric Motors and Drives, Elsevier, 2006.

[10] Jerke, N., Visual Basic 6: The Complete Reference, Osborne, McGraw Hill Pubs, 1999.

[11] Koliopoulos, T., Koliopoulou, G., Evaluation of optimum landfill design: Mid Auchencarroch experimental landfill emissions, In Transactions on Computer Aided Optimum Design in Engineering of Wessex Institute of Technology, Computer Aided Optimum Design in Engineering of Wessex Institute of Technology, vol. 10, 2007, p. 231-239.

[12] Koliopoulos, T.C., Koliopoulou, G., Evaluation of Iso-Butyric Acid and Acetic Acid in Landfill Leachate Emissions - Mid Auchencarroch Experimental Design, Asian Journal of Chemistry, vol. 20, no. 2, 2008, p. 1153-1162.

[13] Koliopoulos, T., Babatsikou, F., Koutis, C., Design Evaluation of a Communal Care Building Facility for People with Alzheimer's Disease, International Journal of Caring Sciences, vol. 9, no. 2, 2016, p. 348-357.

[14] Koliopoulos, T., Babatsikou, F., Koutis, C., Effective Sustainable Design of a Care Communal Building Facility for People with Musculoskeletal Disorders, International Journal of Caring Sciences, vol. 9, no. 2, 2016, p. 704-716.

[15] Blackman, C., Paige, C., Cuffaro, N., Sears, L., Industrial Design, Rockport, USA, 2013. 
[16] Koliopoulos, T.C., Koliopoulou, G., Evaluating Landfill Chemical Emissions Mid Auchencarroch Experimental Design. Asian Journal of Chemistry, vol. 19, no. 5, 2007, p. 3911-3917.

[17] Tchobanoglous, G., Theisen, H., Vigil, S., Integrated Solid Waste Management, McGraw, USA, 1993.

[18] Tchobanoglous, G., Burton, F., Stensel, D., Wastewater Engineering, Treatment and Reuse, McGraw, USA. 2003.

[19] Davie, T., Fundamentals of Hydrology, Routledge, USA, 2008.

[20] Cottingham, M., Mastering AutoCAD VBA, Sybex publications, 2001. 